It All Comes Out: Vomit as a Source of Comedy in Roman Moralizing Texts Author(s): Ian Goh

Source: Illinois Classical Studies, Vol. 43, No. 2 (Fall 2018), pp. 438-458

Published by: University of Illinois Press

Stable URL: https://www.jstor.org/stable/10.5406/illiclasstud.43.2.0438

JSTOR is a not-for-profit service that helps scholars, researchers, and students discover, use, and build upon a wide range of content in a trusted digital archive. We use information technology and tools to increase productivity and facilitate new forms of scholarship. For more information about JSTOR, please contact support@jstor.org.

Your use of the JSTOR archive indicates your acceptance of the Terms \& Conditions of Use, available at https://about.jstor.org/terms 


\title{
It All Comes Out: Vomit as a Source of Comedy in Roman Moralizing Texts
}

\author{
IAN GOH
}

\begin{abstract}
Retching is important for Roman cultural history and medicine; in this article I assess vomit's appearances in Latin literature. Humor is created by the detailed revelation of habitual, inappropriate, and excessive behaviors by named targets, such as the emperors Claudius and Vitellius, and Mark Antony, accused by Cicero in Philippics 2, especially. Alcohol abuse and gluttony feature in invective against character types who vomit, such as the stock figures of the drunken hostess and faithful wife at sea in Juvenal 6, Martial's lesbian Philaenis, and the cautionary tale of the patient who relapses and dies to which the hungover Stoic student is subjected in Persius 3. I end with the self-mocking visualizations of (bad) poetry as vomit in several Horatian passages alongside Nero's voice-training purges.
\end{abstract}

\section{Introduction}

The act of vomiting is itself not a disease, nor need it be a symptom of disease. ${ }^{1}$ However, it is certainly a behavior which occasions moralizing, as it can be the result of the practices, frowned-upon at Rome, of overeating and excessive bibulousness, themselves both the product of a luxurious lifestyle. In this article, I analyze several passages where the denunciation of such a lifestyle results in comic vignettes, which generally deploy absurdity and excess to create an impact. There is a fundamental tension throughout because vomit can be thought of as a cure for overliving through the expulsion of toxins from the body. That said, the principal examples from the moralizing tradition criticize emesis as

1. Editions used: Suetonius's Latin is from Kaster (2016); Tacitus's from Heubner (1983); and Cicero Phil. 2 is quoted from Ramsey (2003); all other excerpts are quoted from the editions, listed below in the translation section, except for the extract of Horace's Epodes, quoted as in Mankin (1995). Translations used: Edwards (2000) for Suetonius; Damon (2012) for Tacitus's Annals; Cary (1914-1927) for Dio; Shackleton Bailey for Cicero's Philippics (2009) and Fam. 12.2.1 (2001); Braund (2004) for Juvenal and Persius; Nisbet (2015) for Martial; Brown (1993) for Horace's Satires 1; Muecke (1993) for Horace's Satires 2; and West (1997) for Horace's Epodes and Ode 1.37; all have been lightly edited.

Illinois Classical Studies, Vol. 43, No. 2, Fall 2018

(C) 2019 by the Board of Trustees of the University of Illinois 
evidence of debauchery or derangement - vomiting as part of an aetiology of disease - rather than its use as a cure for excess; if vomiting's curative properties are put under the satirist's lens, it is because the cure is itself taken too far, and the activity can be targeted as a means "of extending the body's capacity indefinitely."'2

In part, the problem arises because satire, the mode of several of those attacks on luxury, can itself be conceived as the literature of excess, as we might claim most justifiably of the misogynistic screed that is Juvenal 6, though even that, as we shall see, is not unproblematic. Satire bursts its boundaries in its parrhesia and offers wide-ranging, not focused, critique. And the ideas of fluidity and over-consumption, which satire perpetuates, link well, too, with the bodies, ripe for mockery, of satire, arid and sterile, on the one hand, ${ }^{3}$ but also fleshpots of grotesquery on the other. ${ }^{4}$ Contradiction, as I emphasize, is rife: "perhaps the most alarming signal of disgust is vomit, a substance that is both produced by and evokes disgust." ${ }^{5}$ In the final section of this article, we shall observe that vomiting functions not only as a cultural marker for invective but also as a metaphor for literary production itself in literary texts. What I am documenting and examining, then, is the way in which moralizing texts create humor from the predicament of the vomiting individual - that is, in the power relations at stake when the weakened body is laid bare. I will focus exclusively on Latin texts, leery for the most part of Greek influences from Homer, Hipponax, and others, on the rationale that satire is the most Roman of genres and that Hellenic attitudes to vomiting, though influential in many ways (as the circling of this article around the symposium reveals), would confuse a distinctly Roman moralizing picture.

\section{Vomiting by Name}

I start with the most powerful of individuals, namely two emperors, who are revealed to possess weak, wine-soaked constitutions: the portrayals of Claudius and Vitellius as created by Suetonius. First Claudius:

nec temere umquam triclinio abscessit nisi distentus ac madens et ut statim supino ac per somnum hianti pinna in os inderetur ad exonerandum stomachum. (Suet. Claud. 33)

2. Gowers (1993a) 19.

3. Miller (1998).

4. Braund and James (1998), on Sen. Apocol., a text I do not treat here. It is interesting that Plaza (2006) does not seem to mention vomit at all in her monograph on humor in satire.

5. Lateiner and Spatharas (2017) 25, italics in the original. 
He hardly ever left the dinner table without being stuffed with food and overflowing with wine. He would at once lie down on his back, going to sleep with his mouth open, and a feather would be put into his throat in order that he could relieve his stomach.

Then Vitellius:

sed uel praecipue luxuriae saeuitiaeque deditus epulas trifariam semper, interdum quadrifariam dispertiebat in iantacula et prandia et cenas comisationesque, facile omnibus sufficiens uomitandi consuetudine. (Suet. Vit. 13)

Above all, however, he was addicted to luxury and to cruelty, always having at least three feasts, sometimes four in a day - breakfast, lunch, dinner, and a drinking party - and easily finding capacity for it all through regular vomiting.

The question of whether this luxury-loving pair suffered from a kind of bulimia was discussed in a late 20th-century medical journal, ${ }^{6}$ and such a highlighting of these two emperors as particularly extravagant is common. ${ }^{7}$ While we need not condone the late-breaking diagnosis, Suetonius in discussing each emperor plays up the phenomenal, in the sense that it was fitting to be marvelled at, nature of their behavior. Claudius's sleeping with his mouth agape is a brilliant Suetonian vignette, revolting in its physicality and simultaneously explicatory: ${ }^{8}$ for, how else could the feather have been inserted unless the emperor's mouth was already open? ${ }^{9}$

Now compare the account of Claudius's death in Tacitus:

adeoque cuncta mox pernotuere ut temporum illorum scriptores prodiderint infusum delectabili boleto uenenum, nec uim medicaminis statim intellectam, socordiane an Claudii uinolentia; simul soluta aluus subuenisse uidebatur. igitur exterrita Agrippina, et, quando ultima timebantur, spreta praesentium inuidia prouisam iam sibi Xenophontis medici conscientiam adhibet. ille tamquam nisus euomentis adiuuaret, pinnam rapido ueneno inlitam faucibus eius demisisse creditur, haud ignarus summa scelera incipi cum periculo, peragi cum praemio. (Tac. Ann. 12.67)

Everything was so soon known that it is already attested in contemporary writers' accounts: poison infused into a choice mushroom, the drug's power

6. Crichton (1996), dispassionately evaluated by Keel (2017) 46.

7. Cf. Alcock (2003) 12.

8. See Wallace-Hadrill (1995) 149-50 on the extraordinary lack of a tally of virtue and vice in Suetonius's biography of Claudius.

9. Cf. Gladhill (2012) 341 on the description of Claudius's body at Suet. Claud. 30 as "the closure of the animalistic imagery." 
not immediately seen — was Claudius too sluggish or too drunk? - and loosened bowels apparently providing relief. Dismay filled Agrippina and with finality threatening she dismissed present antipathy and deployed the doctor Xenophon's pre-arranged complicity. He, as if assisting Claudius's struggles to vomit, sent down his throat a feather coated with quick-acting poison, so it is believed, perfectly aware that the greatest crimes are begun dangerously but accomplished profitably.

The play on the ignorance of Claudius in relation to the knowingness of Agrippina, the power behind the throne, and her functionary, the doctor Xenophon who is haud ignarus of human nature and crime, is well known. ${ }^{10}$ In this case, the detail of the poisoned feather (pinnam ... inlitam) matches the feather in the Suetonian account of Claudius's regular practice. ${ }^{11}$ There is another correspondence: this climactic poisoning stage-managed by Agrippina is only resorted to when the slow poison she had selected ("She decided on something special, to confound intellect and defer death," exquisitum aliquid placebat, quod turbaret mentem et mortem differret, Ann. 12.66: the decision had been difficult) seems not to have worked. ${ }^{12}$ Therefore, vomiting is ostensibly an unsuccessful "cure," almost as a means of returning the emperor from lethargy to normality; the historian's delicious irony refers to Claudius's normal propensity to inaction.

But while vomiting is supposedly the motivation for the culminating intrigue, it is also juxtaposed with another bodily function: for there is here also a soluta aluus, which seems for the moment to save the emperor but instead damns him to the trick with the feather. Perhaps this midriff foreshadows Agrippina's own death (protendens uterum "uentrem feri" exclamauit, "she thrust forward her middle and cried, 'Hit the belly!,," Ann. 14.8);13 certainly, there is present here the discourse of unblocking passages in the context of medical cure. The bowel movement is a debased reflection of, or a pathetic substitution for, the absent vomit that should — but does not-happen: the reference to it mocks, through the insertion of corporeal crudity, Claudius and the crisis more generally. ${ }^{14}$ Tacitus's sleight of hand is emphasized by Suetonius's record of the death, the second version of which has Claudius vomiting. ${ }^{15}$

10. Keitel (1981) 213-14.

11. See, e.g., Gascou (1984) 289.

12. On haste vs. delay here, see, e.g., Santoro L'hoir (2006) 189.

13. Cf. Edwards (2007) 200 on Agrippina's marriage with Claudius as incest, informing the reading of matricide as rape.

14. "Suppression is also evident" in Tacitus's account: Potter (2012) 134. Sen. Apocol. 4.3 focuses on the excrement.

15. "Some say that he first lost consciousness, then vomited up from his overflowing stomach all he had consumed (cibo affluente euomuisse omnia) but that he was given a second dose of poi- 
As for Vitellius, what of Suetonius's technique is impressive in the extract above is the accumulation of detail. ${ }^{16}$ Having said that Vitellius is good for three or four feasts, four are listed. ${ }^{17}$ The particularity is pointed, because it contrasts with the generalization of the customary vomiting, which can happen at any (or every) time, and which is all-or-nothing. ${ }^{18}$ Suetonius might be said to marvel at Vitellius's apparent stamina. In this connection, it is worth dwelling upon Cassius Dio's account. His version of Vitellius's vices is appropriately lurid: "He was insatiate in gorging himself, and was constantly vomiting up what he ate, being nourished by the mere passage of the food. Yet this practice was all that enabled him to hold out; for his fellow-banqueters fared very badly" (65.2.2). Vitellius's vomiting has a purpose; it allows him to eat again. ${ }^{19}$ Dio also preserves what Morgan calls "the best anecdote," 20 concerning Vibius Crispus, who, when sick and thus absent from Vitellius's banquets, quipped that "if I had not fallen ill, I surely should have perished" from overeating (65.2.3). Again, vomiting as cure stands in the background, in this case as a source of humorous witticism. ${ }^{21}$

It might be thought that such bathetic portrayals of powerful individuals emitting unspeakable matter might be a particular feature of the imperial age, given as it is to the dissection of bodily grotesquery. ${ }^{22}$ Yet earlier, amid the turmoil of the end of the Republic, Cicero had repeatedly referred to vomit

son," Suet. Claud. 44. Champlin (2003) 44-46 stresses the unknowability of events owing to the divergences in our three sources (Cass. Dio 61.34 being the other, who only mentions the effects of strong drink).

16. On the way in which Suetonius craftily couches Vitellius's speech repeatedly in terms of consumption, see Damon (2014) 55.

17. Perhaps such schematics owe something to Suetonius leaning on the physiognomic tradition, for which see Rohrbacher (2010) 94-103.

18. One wonders whether Suetonius reflects, in his itemization of Vitellius's mealtimes against the backdrop of constant vomiting, the infamous all-encompassing meal called "Minerva's Shield" (as described in Suet. Vit. 13, cf. Cass. Dio 65.3, Plin. HN 35.163) that Vitellius invented. Suetonius didn't get the full story there though, for Dio's version reveals that Vitellius also had a silver cooking dish made to fit that meal in, which survived "somewhat in the light of a votive offering," until Hadrian melted it down: Dalby (2001) 72-73.

19. Ash (1999) 99.

20. Morgan (2006) 151.

21. Tacitus's portrayals of Vitellius's tendency to excess are relatively muted, and tend not to obsess over his vomiting as opposed to his inertia, probably because the historian seeks to differentiate his work from that of the Flavian hagiographers: see Ash (1999) 114 on Tac. Hist. 2.62; cf. also Hist. 1.62, 2.68, 2.71, 2.95 .

22. On the Neronian interest in dismemberment, see, for example, Most (1992); on "bodily ecphrasis" as a preoccupation of Suetonius especially, see Gladhill (2012). 
in his invective against Mark Antony, the second Philippic. Cicero consistently and uncharitably exploits instances of Antony's being suddenly taken ill (especially once at a tribunal he was holding in the relatively unimportant Porticus Minucia, as we learn at Phil. 2.84) as evidence of his proclivity towards carousing, moral depravity rather than physical disease. Antony cannot comport himself appropriately in public and thus defiles public office and religion: ${ }^{23}$

tu istis faucibus, istis lateribus, ista gladiatoria totius corporis firmitate tantum uini in Hippiae nuptiis exhauseras ut tibi necesse esset in populi Romani conspectu uomere postridie. o rem non modo uisu foedam sed etiam auditu! si inter cenam in ipsis tuis immanibus illis poculis hoc tibi accidisset, quis non turpe duceret? in coetu uero populi Romani negotium publicum gerens, magister equitum, cui ructare turpe esset, is uomens frustis esculentis uinum redolentibus gremium suum et totum tribunal impleuit. sed haec ipse fatetur esse in suis sordibus. (Cic. Phil. 2.63)

With that gullet of yours, that chest, that robust physique befitting a gladiator, you engulfed such a quantity of wine at Hippias's wedding that the following day you found it necessary to vomit in full view of the Roman people. Disgusting to witness, disgusting even to hear tell of! Had this happened to you at dinner in those same monstrous cups of yours, who would not think it a shameful exhibition? But while conducting public business, in a gathering of the Roman people in his role as Master of the Horse, for whom it would be disgraceful to burp, he vomited, filling his lap and the whole platform with morsels of food stinking of wine! Ah well, he admits himself that this was one of his less creditable performances.

Cicero lays it on thick, discounting any less charged reason for vomiting than the after-effects of Antony's typical bibulousness. ${ }^{24}$ Compare the abstemiousness of Augustus, in Suetonius's account:

non amplius ter bibere eum solitum super cenam in castris apud Mutinam Cornelius Nepos tradit; postea quotiens largissime se inuitaret, senos sextants non excessit aut, si excessisset, reiciebat. (Suet. Aug. 77)

Cornelius Nepos writes that in camp before Mutina it was his habit to drink not more than three times at dinner. Afterwards, when he indulged most freely he never exceeded a pint; or if he did, he used to throw it up.

23. Craig (1993) 152-53 and, more broadly, Edwards (1993) 191-92.

24. As Ramsey (2003) 252 notes, citing President G. H. W. Bush's travails on a visit to Japan in 1992. 
Augustus's vomiting reflects his virtue, and while the specific detail of the "three times" he drinks at dinner is reminiscent of Vitellius's "three or four feasts," the ambiguity of "afterward" (postea meaning "after dinner" just as much as "after Mutina") allows for the Augustus's overindulgence, tempered as it is, to be excused: if the vomiting happens after dinner, then it is restricted in time, unlike Antony in the senate house or Vitellius throughout the day. ${ }^{25}$

The alcoholism theme is an easy crutch for Cicero's excoriation of Antony's flaws throughout the speech: ${ }^{26}$ the first explicit mention of "doziness" (stupor) is at 2.30, describing Antony's paranoid (so to speak) labelling of Cicero as a party to the conspiracy to murder Caesar, and it ascends in the same paragraph to the injunction, "rouse yourself from your intoxication, I say, and blow it all out" (edormi crapulam, inquam, et exhala). Soon after, Cicero encourages Antony to behave like a "sober man" (sobrii hominis, 2.31). That imperative exhala ostensibly suggests "working off the effects of alcohol by vigorous exercise,"27 though it also could mean vomiting, in a foreshadowing of a jibe which Cicero deploys soon after:

ibi te cum et illius largitionibus et tuis rapinis expleuisses, si hoc est explere, haurire quod statim effundas, aduolasti egens ad tribunatum, ut in eo magistratu, si posses, uiri tui similis esses. (Cic. Phil. 2.50)

When you had glutted yourself there with Caesar's largess and your own plunderings - if glut is the word for gobbling down one minute to throw up the next-impoverished you swooped down on the tribunate, with the intention, if you could, of performing in that office like your-husband.

Again, there is a lack of self-control throughout Antony's life ${ }^{28}$ as is manifested in his fighting of the civil war, which Cicero describes as "saturating himself with the blood of fellow countrymen who resembled him not at all" (saturauit se sanguine disimillimorum sui ciuium, 2.59), later even more explicitly, "you had tasted the blood of your fellow countrymen, or rather drained it" (gustaras ciuilem sanguinem uel potius exsorbueras, 2.71). Romans' blood is here visualized as the wine for Antony's extravagant drinking binges.

Antony attempted to reach Spain in the war, but was stranded in Narbo, where Cicero alleges that he outsourced the fighting to Dolabella, while he would

25. It is well known that Augustus possessed a weak constitution, as Suet. Aug. 81 reveals (with illnesses mentioned at 8, 13, 28, 43, 59, 91, 97 and 98).

26. And in letters as well: Fam. 12.2.1, 12.25.4. Vomiting is one of the "images that tend to hold the long speech together and to make its impact more forceful": Wooten (1983) 55. Cf. Köster (1980) 130.

27. Ramsey (2003) 207.

28. The same behavior is characterized with the similar word ingurgitasset at Cic. Phil. 2.65. 
"vomit over your hosts' dinner tables" (2.76). It turns out, though, that all of the instances which Cicero produces, public or private, feature Antony encroaching on others - barf as a bad business in houses which are not his own. ${ }^{29}$ This can be clearly seen in the infamous incident in the Porticus Minucia, but also elsewhere in Cicero's second Philippic:

haec ut colligeres, homo amentissime, tot dies in aliena uilla declamasti? quamquam tu quidem, ut tui familiarissimi dictitant, uini exhalandi, non ingeni acuendi causa declamitas. (Cic. Phil. 2.42)

Was it to rake all this stuff together, you addle-brain, that you spent all these days declaiming in a country house that does not belong to you? Though, to be sure, you do that to clear your head of intoxication from wine, not to sharpen your wits; that's what your closest friends claim.

So, too, Antony's tour of Rome takes in Varro's villa at Casinum, appropriated by underhand means, as Cicero insinuates:

at quam multos dies in ea uilla turpissime es perbacchatus! ab hora tertia bibebatur, ludebatur, uomebatur. o tecta ipsa misera, 'quam dispari domino'-quamquam quo modo iste dominus? — sed tamen quam ab dispari tenebantur! studiorum enim suorum receptaculum M. Varro uoluit illud, non libidinum deuersorium. (Cic. Phil. 2.104)

But how many days did you spend disgracefully carousing in that villa! From eight o'clock in the morning there was drinking, gambling, vomiting. I pity the very building. "How different an owner"-not that Antonius was the owner-but still, how different was the man who occupied that property! Marcus Varro intended it to be a retreat for his studies, not a den of vice.

These alternative loci may function as distancing ploys, to make Antony an outsider in multiple ways, his conduct requiring holding at arm's length. ${ }^{30} \mathrm{Hu}-$ miliatingly, he is repeatedly revealed as an inappropriate house guest and abuser of friendship: this is the very charge he had laid against Cicero in the speech to which Philippics 2 is the answer. ${ }^{31}$ Moreover, the consistently sensationalist presentation of Antony's supposed tendency to overindulgence and then

29. In Fam. 12.2.1, as well, Antony "spent many days 'studying' his speech in the villa of Metellus."

30. This is after all the aim of invective, "to exclude the potential lawbreaker from the community of the elite": Corbeill (2002) 198.

31. Hence it forms part of Cicero's use of antikategoria, turning back a charge against one's accuser: Craig (1993) 153. Cf. Williams (2012) 38 on Antony's violation of the laws of friendship by reading a letter of Cicero out in public (treated at Phil. 2.7). 
vomit allows Cicero to emphasize that the vomit is a debased replacement for, denigrated as inferior to, the production of words and upholding of order. This "fact" is underlined by the contrast with Varro and his studies, which would include the production of literature such as the De Re Rustica - a work that, in its focus on toil leading to material gain, ${ }^{32}$ would itself subtly rebuke Antony's lavish exploitation of others' generosity, another major focus of the speech. ${ }^{33}$

In private, Cicero continues the theme, as in ad Familiares 12.2.1 to Cassius (murderer of Julius Caesar): "So, as I wrote to you earlier, everyone thought he was not speaking but vomiting - according to habit!" But in the speech Cicero flips that jibe when he uses the mere threat of Antony vomiting to increase the effectiveness of his own utterances: "He doesn't disguise it, Members of the Senate; his agitation is evident; he sweats, turns pale. Anything, as long as he doesn't do what he did in the Colonnade of Minucius!"' (2.84). The constellation of warning signs that Antony will vomit then and there becomes a marker of the success of Cicero's speech, itself a pouring-out of invective, as effective as Antony's wine at provoking a response. ${ }^{34}$ The mock-horror at Antony's "true" reactions, the phenomenology of his ailment and his guilt, serves to criticize the target's attitude to the state, again with the withering implication that Antony cannot muster a comprehensible reply and so should remain silent, bottling it up.

\section{Vomiting in Groups}

The previous passages have involved named targets, but mockery of vomitingbased, as in the Ciceronian examples, on a disease which we might tentatively hypothesize is essentially alcohol abuse — can be extended to vilify whole groups. A passage from Juvenal 6 provides the fullest picture of this tendency: ${ }^{35}$

conuiuae miseri interea somnoque fameque urguentur. tandem illa uenit rubicundula, totum oenophorum sitiens, plena quod tenditur urna admotum pedibus, de quo sextarius alter ducitur ante cibum rabidam facturus orexim, dum redit et loto terram ferit intestino. marmoribus riui properant, aurata Falernum peluis olet; nam sic, tamquam alta in dolia longus

32. Kronenberg (2009) 94-107, e.g., "in book 3, a villa is defined by the fact that it makes a profit, regardless of what kind of animal the profit is from" (95).

33. See, for example, Angel (2008) on how Cicero negates the claims of Antony's supporters regarding clemency and obligations, usually Caesar's.

34. Cf. Köster (1980) 133 on 2.104: "Im Punkt der ebrietas brauchte er wohl nicht um Glaubwürdigkeit zu bangen."

35. Linked with Phil. 2.63 by Larmour (2016) 138. 
deciderit serpens, bibit et uomit. ergo maritus nauseat atque oculis bilem substringit opertis. (Juv. 6.424-33)

\begin{abstract}
All this time, her miserable dinner guests are overwhelmed by sleepiness and hunger. Eventually, she arrives, face flushed and thirsty enough for the whole flagon of wine which is set at her feet bulging with its full three gallons. From this she downs two pints before dinner, to create a raging appetite, until it all comes back up and hits the ground along with her washed-out insides: streams are running all over the marble floors and the gilded basin stinks of Falernian. It's like the long snake that's fallen into a deep vat, that's exactly how she boozes and spews up. No wonder her husband feels sick and closes his eyes to keep down his bile.
\end{abstract}

In the scandalous portrait of the woman who is late to the dinner party she herself is hosting, she turns up and drinks to excess, which causes her to throw up on the floor and in a sink. It is with difficulty that her weak husband restrains his sympathetic vomiting. The concentration on extremes is obvious: the woman's thirst for the totum oenophorum, the plena urna, the rabidam orexim, the last debased by an unusual word rare in classical Latin. ${ }^{36}$ To continue, on the linguistic level: the interplay of the future participle facturus to denote purpose and the dum which depends on it coexists with the conceit that the present-tense verbs redit and ferit have no subject expressed, so while obviously it is vomit which is meant, the matrona who vomits (who has just come home, unlike Antony who does so on others' property) could also be understood as the subject: she is what she throws up. Indeed, her purged intestines - for what is happening is an emetic dieting regime familiar from sources such as Pliny the Elder ${ }^{37}$ - seem to accompany her vomit on the way out. The passage continues with a parody of a genre scene describing, for example, a fountain, and an awful contrast between the luxuriousness of the opulent setting and the disgusting practice. Again, we have intricate patterning, and this is true also of the passage's opening, where the flushed red face of the matrona who has exercised (and indeed been brought to climax before this extract begins by the fingering of her male masseuse) mirrors a possible color for the wine - those lower in quality and thus available in bulk, or stored for a long time, likely to be red. ${ }^{38}$

The passage ends with an exemplary turn of moralizing humor, in its allusion to animal fable. We have not only an objectification of the matrona as a snake (which was supposedly fond of wine), ${ }^{39}$ but also a reference to a fable

36. Watson and Watson (2014) 216.

37. Plin. $H N 14.139,14.143$, Sen. Dial. 1.3.13, 12.10.3.

38. Cf., e.g., Laubenheimer (2013) 104 (in a study of amphorae in shipwrecks), with Dalby (2003) 352-53.

39. Courtney (1980) 318. 
found in many different guises in ancient literature, most notably much later in Gregory of Tours's History of the Franks, involving a snake which greedily drinks wine by falling into a wine-jar and cannot get out; the wine-jar's owner mocks the snake, telling it to vomit out what it had drunk (Hist. Franc. 4.9). ${ }^{40}$ The didacticism does not work well for Gregory's fable-teller Theodovald - it apparently made him both feared and hated-but it serves in narrative terms to anticipate the passage's end, by setting the final salvo as a moral or a proverb, with the henpecked husband trying not to ape his wife's vomiting behaviors by essentially turning a blind eye. One interesting aspect then is that this echoes a passage earlier in this long rant of a poem, where Juvenal's persona inveighed against adulterous wives, while invoking faithful ones as collateral damage:

si iubeat coniunx, durum est conscendere nauem,

tunc sentina grauis, tunc summus uertitur aer:

quae moechum sequitur, stomacho ualet. illa maritum

conuomit, haec inter nautas et prandet et errat

per puppem et duros gaudet tractare rudentis. (Juv. 6.98-102)

If it's her husband who tells her to, it's hard to board a ship. That's when the bilge water is sickening, that's when the sky wheels round and round. But the woman who's accompanying her lover has a strong stomach. The other one pukes all over her husband, but this one takes her food with the sailors and wanders all over the deck and enjoys handling the rough ropes.

Here the faithful wife sinks to the decks in a faint, and she vomits on her husband, the rare word conuomere implying in con- not sympathetic vomiting as in the later passage but intensification and instantaneous occurrence. Reading these two extracts in conjunction is illuminating. Doing that uncovers in the seafaring passage hints of the "symposium at sea" trope, ${ }^{41}$ and thus implies drunkenness (with the realistic word sentina meaning more than just bilge-water). ${ }^{42}$ It makes us revaluate the narrator's credibility on the issue of fidelity in the drunkenness scene: for the matrona there had been sexually available just before, which is why she was late, yet the passage ends with a renewed instance of conuomere.

Now, it is agreed in the scholarship on the Juvenal 6 drunkenness passage that here is an adaptation of an epigram by Martial about the lesbian Philaenis, who parades her aggressively masculine appetites: ${ }^{43}$

40. First at Herrmann (1948) 199.

41. As described by Slater (1976).

42. The passage is used by Jones (2007) 98 as evidence that "satire has little use for journeying as an epic index": vomiting is in this conception un-epic.

43. Conveniently in Colton (1991) 256-58. 
nec cenat prius aut recumbit ante quam septem uomuit meros deunces; ad quos fas sibi tunc putat redire, cum coloephia sedecim comedit. post haec omnia cum libidinatur, non fellat — putat hoc parum uirilesed plane medias uorat puellas.

di mentem tibi dent tuam, Philaeni, cunnum lingere quae putas uirile. (Mart. 7.67.9-17)

And she won't eat dinner or recline at table before she's thrown up a good six pints of unmixed wine- which she thinks it's alright to come back to, once she's wolfed down sixteen rib-eyes. When she's done with all this, she sates her lust. She doesn't suck cock - that's not macho enough for her; instead she absolutely gobbles up girls' middles. May the gods bring you to your senses, Philaenis, for thinking it macho to lick cunt.

The adaptation is quite close, and reproduced above is only the second half of the epigram which is relevant to the present theme of vomiting: Martial and Juvenal both have weight-lifting and rough play with the personal trainer, but Juvenal ups the ante with "a wealth of revolting detail absent from Martial."44 Yet Juvenal has erased the anti-lesbian invective, by only keeping the nonsexual elements. ${ }^{45}$ His persona seems to shrink from engaging that particular taboo in this part of Satire 6 (it is present elsewhere). Note that it is arguable that inappropriate gender-switching is still at issue: the younger Seneca, in his letter 95, includes vomiting as one of the masculine vices which women have appropriated ${ }^{46}$ Then what is the laughable disease here? For Juvenal, where the snake fallen into the wine-bucket provides further amplification of the matrona falling about, head in the sink, we might say, as I did earlier, that it is alcoholism. Yet there is a tentative adumbration of another diagnosis: conduct inappropriate to one's gender, or conversely all too appropriate to it. Women, in Juvenal's persona's eyes (or perhaps better, his myopia), are the disease.

Continuing this trait of metonymy is the aftermath of a boozy night out in the opening of Persius's Satire 3, where the persona wakes up late, hungover: "we're snoring enough to make the untamed Falernian stop fizzing" (stertimus,

44. Watson and Watson (2014) 212. One might wonder whether Martial's name, Philaenis, which is suppressed in Juvenal's portrait (where there is a husband), refers to a "love of bronze drinking vessels" (aenum being a "cauldron," aeneus meaning "bronze") - appropriate even to the "snake in the vat" story.

45. Richlin (1992) 134.

46. Larmour (2016) 41-42. 
indomitum quod despumare Falernum/sufficiat, Pers. 3.3-4). While this seems to mean that the snoring accompanies digestion, alternative valid meanings are that the wine goes flat, ${ }^{47}$ in which case the student speaker is akin to the receptacle for the wine (looking forward to the description of him as clay to be molded, 3.21-4), or that the Falernian spews forth (like the snoring). ${ }^{48} \mathrm{~A}$ little later, as the poem gets going, the lazy student's "green bile is swelling" (turgescit uitrea bilis, 3.8) in a sure sign of retching to follow. ${ }^{49}$ It is no coincidence that the climax of Persius 3 comes full circle with a grand Guignol death scene: ${ }^{50}$

turgidus hic epulis atque albo uentre lauatur, gutture sulpureas lente exhalante mefites. sed tremor inter uina subit calidumque trientem excutit e manibus, dentes crepuere retecti, uncta cadunt laxis tunc pulmentaria labris. hinc tuba, candelae, tandemque beatulus alto conpositus lecto crassisque lutatus amomis in portam rigidas calces extendit. at illum hesterni capite induto subiere Quirites. (Pers. 3.98-106)

Stuffed from the feast this one goes to bathe, his belly white, his throat emitting long sulphurous stenches. But as he drinks, a fit of shivers comes over him and knocks the hot glass out of his hands, his bared teeth chatter, then the lavish flavorings slide from his slack lips. Then come the trumpet and candles, and finally the dear deceased, laid out on a high bier and plastered thick with perfumed balm, sticks out his stiff heels towards the door. And it's yesterday's new citizens wearing their new hats that carry him out.

Here is a quasi-parable of the sick man who doesn't take his doctor's or friend's advice, goes to the bath, drinks, and then expires. ${ }^{51}$ We may concentrate on just one line, 102, which is the last in the description of the man's death. Already he has been burping, and his disease then comes to a head: dropping the glass, he shivers with an echo of a death-rattle, and finally the food falls from his lips. Of course, this is different from the projectile vomit of the Juvenal passages, primarily because of the loose lips: it is slack-jawed incapability to eat, not

47. Cf. Sen. De Ira 2.20, Ep. 99.27.

48. Cf. Lucan 6.506; Kissel (1990) 377 seems to favor this explanation in his discussion.

49. On the contradictions of the braying voice full of bile coming "from the man who criticizes asses' ears," see Bartsch (2015) 197.

50. Linked to the poem's opening by Reckford (1998) 348, for example, and to the Juv. 6.425-32 passage by Miller (2012) 328.

51. Cf. Miller (2012) 325-26: "it is the feast itself that has become the sign of death" (325). Bartsch (2015) 42 reads the ailment as Thyestes-style cannibalism. 
necessarily regurgitation. But in view of the infamous prominence of vomit, or attempted vomiting, at deaths such as that of Claudius as discussed earlier, it is reasonable to assume its presence in the background here, in part because of the striking reference to Quirites, also because of the clear social status of the deceased. Notice too that the dying man's teeth aren't used for eating, but rather crepuere. Essentially it seems that vomiting is both oddly unnatural-for food should be digestible - and yet, if we see it in Persius 3.102, it is part of the process of dying, which is common to all: both of these are a far cry from vomit as cure.

\section{Poets' Vomit}

Such constructions have already had a personal tinge in Horace, Persius's avowed model. ${ }^{52}$ The first of Horace's comments on the subject has the everyman poet-traveller, Horace's persona itself, suffering in mock-heroic mode with a bout of food poisoning which could well involve vomiting as well as or instead of diarrhea: ${ }^{53}$

hic ego propter aquam, quod erat deterrima, uentri indico bellum, cenantis haud animo aequo

exspectans comites. (Hor. Sat. 1.5.7-9)

Here, on account of the water, which was quite terrible, I declared war on my stomach, and waited, ill at ease, for my companions to dine.

Poetic production stemming from a sympotic context, meaning the reporting of the conversations of friends at dinner (which is the very nature of Horatian sermones, "conversations," as his book is titled), is impossible. Yet poetry, in the form of Satire 1.5 itself, does occur. ${ }^{54}$ Indeed, the mock-epic phraseology of this "declaration of war," followed by fretting (haud aequo animo) which could be the puzzlement of composing poetry, confirms that the disease now is not only food poisoning, but also the production of sub-standard verse. The Satire 1.5 upset stomach shows us a powerless and even emasculated poet (as the remainder of the poem, with its unsuccessful sexual tryst and wet dream, will bear out).

52. Hooley (1997) 202-29 reads Pers. 3 alongside Hor. Sat. 2.3 but without a focus on the closing passage; for Horace there see Bartsch (2015) 41.

53. Most assume diarrhea, as does, for example, Schlegel (2005) 63. Gowers (2012) 189 offers only two options here: "either H. has dysentery and starves his stomach into surrender, i.e., abstinence; or he cuts off suspect supplies in the first place"; earlier "an attack of typhoid" had been diagnosed: Gowers (1993b) 56. Both typhoid and dysentery can have vomiting as a symptom.

54. See Reckford (1999) on the question of when and how the poem might have been written. 
Likewise, Furius, a not-really-identifiable poetaster, ${ }^{55}$ in the same poet's Satire 2.5 , vomits gobbets:

persta atque obdura, seu rubra Canicula findet

infantis statuas seu pingui tentus omaso

Furius hibernas cana niue conspuet Alpis. (Hor. Sat. 2.5.39-41)

Stand fast and endure, whether the red Dogstar splits unspeaking statues or whether, swollen with rich tripe, Furius bespatters the wintry Alps with white snow.

Horace means that Furius extrudes words (about snow?), but the spew of "snow" presumably also consists of the tripe he didn't digest. The incongruity is exaggerated, for how could Furius perform this action unless he were standing in the Alps (or is a weather system, on analogy with the Dogstar)? ${ }^{56}$ Certainly, the trope of the bad writer spewing forth looks forward to the mad poet of the Ars Poetica, from the end of Horace's poetic career, who explodes, or to be precise expels: hic dum sublimis uersus ructatur et errat ("While [the mad poet] vomits out his sublime verses and wanders about," Ars P. 457). Again, a natural phenomenon serves as a comparandum, for the poem soon after features Empedocles, another inferior poet, jumping into the volcano, Mt Etna, which could be said to belch out flame. ${ }^{57}$

That vomit is the province of the mediocre author-Horace's inclusion of himself in this group, in Satires 1.5, is explicable as false modesty occasioned by his self-consciously writing in a humble genre - clarifies its appearance in the portrayal of the Emperor Nero:

paulatim et ipse meditari exercerique coepit neque eorum quicquam omittere quae generis eius artifices uel conseruandae uocis causa uel augendae factitarent, sed et plumbeam chartam supinus pectore sustinere et clystere uomituque purgari et abstinere pomis cibisque officientibus. (Suet. Ner. 20)

He began himself to study and practice little by little, omitting none of those exercises by which artists of that kind preserve and strengthen their voices. Rather, he would lie on his back, holding a lead tablet on his chest,

55. Usually, following the scholia, this incompetent poet is seen to be Furius Bibaculus, but Kruschwitz (2010) is very persuasive in counselling caution.

56. Furius's activity has a certain air of "carrying coals to Newcastle" about it — as the Alps might already be covered with snow: see Hor. Sat. 1.10.34-5 where a similar metaphor is employed.

57. And more than that: Diog. Laert. 8.69 claims that the failure of Empedocles's attempted apotheosis "was revealed when the volcano erupted and returned one of his sandals": Rudd (1989) 227. Oliensis (1998) assimilates Etna to "women's nether parts" and the "voracious leech" which closes the poem (217), and also calls Etna one of the poem's closural "grave sites" (223). 
and cleanse his system with a syringe and with vomiting, and he would abstain from fruits and other foods harmful to the voice.

Nero's voice exercises, regulating his system, include vomiting as techniquebut do they make him an "artist of that kind"? Given the effeminacy and inappropriateness of Nero's theatrical habit, humor arises from the misapplication of natural or curative emesis - in this case, through the detailed and extreme exertions of training - as much as from the shock value of mentioning the act. ${ }^{58}$ In Horace's Epode 9, vomit had also been curative, when wine served, it has been argued, to alleviate the nausea of seasickness: ${ }^{59}$

capaciores affer huc, puer, scyphos

et Chia uina aut Lesbia

uel quod fluentem nauseam coerceat, metire nobis Caecubum. (Hor. Epod. 9.33-6)

Bring more capacious goblets, boy, and Chian wine and Lesbian, or dose us with the Caecuban-seasickness must be checked.

Is the wine served because it promotes vomit, to cancel out the seasickness in a "hair of the dog" fashion? ${ }^{60}$ In this case, the poem itself, which celebrates victory at the Battles of Naulochus and of Actium (not to mention the cancellation of wine rationing, as motivates Ode 1.37.1, "now we must drink" (nunc est bibendum), could be that vomit. Or is the Caecuban wine, rather, useful because it can soothe an aching stomach and prevent vomit ${ }^{61}$ The inconsistency is, as we have seen throughout with the critique of disgusting yet necessary bodily functions, part of the point: 62 Horace is supposedly rejoicing at the completion of battle, yet is still anxious (curam metumque, 9.37) and on board a ship. Thus, the laughter occasioned by the revelation of his seasickness points to this poet's lack of fitness for the fight, a cowardice which again manifests itself in physical grotesqueness - reflective, perhaps, of Horace's infamous anxieties over once having been on the wrong side of battle, against Octavian at Philippi.

58. See on Nero's disgusting body on stage Skotheim (2017).

59. Deriving nausea from Greek vaṽ c. Watson (2003) 335-36 prefers $f l u o$ - which is noted to suggest diarrhea not vomit at, e.g., Cels. 3.6.15-to refer to a 'heaving' stomach.

60. Plin. $H N 23.38,23.43$ seems applicable here despite the cavils of Watson (2003) 336.

61. Johnson (2012) 135 (who plumps for "vomiting, not a pleasant experience" as the referent) thinks the order of Caecuban is indefinitely delayed here.

62. Further inconsistency is created by the "theory of the two Caecubans" (see Giusti [2016] 135) and the problem of it being not just a waste of good wine but a sacrilege (nefas, Hor. Carm . 1.37.5) to bring it out expediently. Mankin (1995) 181 sees "a certain poignancy" in the wine becoming "a battlefield ration." 
Thinking about Epode 9 as, like Ode 1.37 and the other examples collated in this article, a response to gender confusion, in this case at the Battle of Actium, with Cleopatra at one point in the ascendancy, allows us to posit a line of succession for the "symposium at sea" topos down to Juvenal 6. But, as we have seen in these predominantly Horatian examples, such a tradition prominently features the complication of self-mockery when it is linked to literary production. When the writing impulse can be transformed into a metaphorical ailment, then the trustworthiness of reportage is called into question. Indeed, if the stomach is "the body part that engenders bad temper," 63 then vomiting to relieve pressure on that organ might be seen as reducing anger, a worthwhile trait — but one which obviates the rationale for invective, with its need to express indignation.

So, whether the genre is historical, oratorical, or satiric, in Latin literature the mention of vomit occurs in a discourse which seeks to push the boundaries of what is enough or acceptable. This article has cycled through numerous examples whose humor displays a delicate negotiation between the sordid reality of emesis occasioned by actual disease and attempted cures, and the fantastical extremities of imagined luxury. In such a heady literary environment, it is no accident that the word Suetonius uses for Vitellius's living up to his feasting tendencies, sufficiens (Vit. 13), has another meaning apart from "being sufficient": sufficio can also imply "substitution" and therefore "choosing" or "appointing" in the place of another (OLD a2 s.v. sufficio) - which is nicely ironic in the description of an emperor who only briefly occupies the role. As well as that, sufficiens means "satisfying," "being enough," and the idea of "what is satis," policing respectability, is fundamental to the genre of satire. ${ }^{64}$ Such an observation shows that even at the very margins of our enquiry, detail is employed to render the portraits of the (even momentarily) out-of-control targets holistic. The very nature of vomit is generally disreputable, then, in its closeness to ideas of excess; nonetheless, both the laughter and the tut-tutting it occasions reveal, in particular through the emphasis we have seen throughout on control over the right time for both the action and reactions to it, the innate character of its (often) hapless practitioner and chastising critic alike. ${ }^{65}$

Swansea University

i.k.1.goh@swansea.ac.uk

63. Gowers (2012) 189 on Sat. 1.5.6-7, cf. Keane (2015) 32 with Hoffer (2007) on Cicero's deployment of the noun stomachus to mean "anger."

64. Cf. Haynes (2003) 78-79 on different significations of sufficere at Tac. Agr. 45.2.

65. I would like to thank the editors for their original invitation, help, support, and forbearance. 


\section{Works Cited}

Alcock, J. P. 2003. "Gluttony: The Fifth Deadly Sin.” In H. Walker, ed., The Fat of the Land: Proceedings of the Oxford Symposium on Food and Cookery, 11-21. Bristol: Footwork.

Angel, N. 2008. "Clementia and Beneficium in the Second Philippic." In T. Stevenson, M. Wilson, eds., Cicero's Philippics: History, Rhetoric, Ideology, 114-30. Auckland: Polygraphia.

Ash, R. 1999. Ordering Anarchy: Armies and Leaders in Tacitus' Histories. London: Duckworth.

Bartsch, S. 2015. Persius: A Study in Food, Philosophy, and the Figural. Chicago: University of Chicago Press.

Braund, S. M., ed. and trans. 2004. Juvenal and Persius. Cambridge, MA: Harvard University Press.

Braund, S. M., and James, P. 1998. “Quasi Homo: Distortion and Contortion in Seneca's Apocolocyntosis." Arethusa 31: 285-311.

Brown, P., ed. 1993. Horace: Satires Book 1. Warminster: Aris and Phillips.

Cary, E., ed. and trans. 1914-1927. Cassius Dio Cocceianus: Roman History, Volumes 1-9. London: Heinemann.

Champlin, E. J. 2003. Nero. Cambridge, MA: Harvard University Press.

Colton, R. E. 1991. Juvenal's Use of Martial's Epigrams: A Study of Literary Influence. Amsterdam: Hakkert.

Corbeill, A. 2002. “Ciceronian Invective.” In J. M. May, ed., Brill's Companion to Cicero: Oratory and Rhetoric, 197-217. Leiden: Brill.

Courtney, E. 1980. A Commentary on the Satires of Juvenal. London: Athlone Press.

Craig, C. P. 1993. Form as Argument in Cicero's Speeches: A Study of Dilemma. Atlanta: Scholars Press.

Crichton, P. 1996. "Were the Roman Emperors Claudius and Vitellius Bulimic?" International Journal of Eating Disorders 19: 203-7.

Dalby, A. 2001. "Dining with the Caesars." In H. Walker, ed., The Fat of the Land: Proceedings of the Oxford Symposium on Food and Cookery, 62-88. Bristol: Footwork. 2003. Food in the Ancient World from A to Z. London: Routledge.

Damon, C., trans. 2012. Tacitus. Annals. London: Penguin Books.

- 2014. "Suetonius the Ventriloquist." In T. Power and R. K. Gibson, eds., Suetonius the Biographer: Studies in Roman Lives, 38-57. Oxford: Oxford University Press.

Edwards, C. 1993. The Politics of Immorality in Ancient Rome. Cambridge: Cambridge University Press.

— University Press.

- 2007. Death in Ancient Rome. New Haven: Yale University Press.

Gascou, J. 1984. Suétone Historien. Rome: École française de Rome. 
Giusti, E. 2016. "Dithyrambic Iambics: Epode 9 and its General(s') Confusion." In P. Bather, C. Stocks, eds., Horace's Epodes: Contexts, Intertexts, and Reception, 131-49. Oxford: Oxford University Press.

Gladhill, B. 2012. "The Emperor's No Clothes: Suetonius and the Dynamics of Corporeal Ecphrasis." ClAnt 31: 315-48.

Gowers, E. 1993a. The Loaded Table: Representations of Food in Roman Literature. Oxford: Clarendon Press.

- 1993b. "Horace, Satires 1.5: An Inconsequential Journey." PCPhS 39: 48-66. , ed. 2012. Horace: Satires Book I. Cambridge: Cambridge University Press.

Haynes, H. 2003. The History of Make-Believe: Tacitus on Imperial Rome. Berkeley, Los Angeles: University of California Press.

Herrmann, L. 1948. “Autour des Fables de Phèdre.” Latomus 7: 197-207.

Heubner, H., ed. 1983. P. Cornelii Taciti Libri Qui Supersunt: Tom. I: Ab Excessu Diui Augusti (Annales). Stuttgart: Teubner.

Hoffer, S. E. 2007. “Cicero's 'Stomach': Political Indignation and the Use of Repeated Allusive Expressions in Cicero's Correspondence." In R. Morello, A. D. Morrison, eds., Ancient Letters: Classical and Late Antique Epistolography, 87-106. Oxford: Oxford University Press.

Hooley, D. M. 1997. The Knotted Thong: Structures of Mimesis in Persius. Ann Arbor: University of Michigan Press.

Johnson, T. S. 2012. Horace's Iambic Criticism: Casting Blame (Iambikē Poiēsis). Leiden: Brill.

Jones, F. 2007. Juvenal and the Satiric Genre. London: Duckworth.

Kaster, R. A., ed. 2016. C. Suetoni Tranquilli De Vita Caesarum Libros VIII et De Grammaticis et Rhetoribus Librum. Oxford: Oxford University Press.

Keane, C. 2015. Juvenal and the Satiric Emotions. Oxford: Oxford University Press.

Keel, P. 2017. Eating Disorders. 2nd ed. Oxford: Oxford University Press.

Keitel, E. 1981. "Tacitus on the Deaths of Tiberius and Claudius." Hermes 109: 206-14.

Kissel, W., ed. 1990. Aules Persius Flaccus Satiren. Heidelberg: Carl Winter Universitätsverlag.

Köster, S. 1980. Die Invektive in der griechischen und römischen Literatur. Meisenheim am Glan: Hain.

Kronenberg, L. 2009. Allegories of Farming from Greece and Rome: Philosophical Satire in Xenophon, Varro, and Virgil. Cambridge: Cambridge University Press.

Kruschwitz, P. H. P. 2010. "Gallic War Songs: Furius Bibaculus' Annales Belli Gallici." Philologus 154: 285-305.

Larmour, D. H. J. 2016. The Arena of Satire: Juvenal's Search for Rome. Norman, OK: University of Oklahoma Press.

Lateiner, D., Spatharas, D. 2017. "Introduction: Ancient and Modern Modes of Understanding and Manipulating Disgust." In D. Lateiner, D. Spatharas, eds., The Ancient Emotion of Disgust, 1-42. Oxford: Oxford University Press. 
Laubenheimer, F. 2013. "Amphoras and Shipwrecks: Wine from the Tyrrhenian Coast at the End of the Republic and its Distribution in Gaul." In J. Derose Evans, ed., A Companion to the Archaeology of the Roman Republic, 97-109. Malden, MA: Blackwell Publishing.

Mankin, D., ed. 1995. Horace: Epodes. Cambridge: Cambridge University Press.

Miller, P. A. 1998. "The Bodily Grotesque in Roman Satire: Images of Sterility." Arethusa 31: 257-83.

2012. "Imperial Satire as Saturnalia." In S. Braund, J. Osgood, eds., A Companion to Persius and Juvenal, 312-33. Malden, MA: Blackwell Publishing.

Morgan, M. G. 2006. 69 A.D.: The Year of the Four Emperors. New York: Oxford University Press.

Most, G. W. 1992. "Disiecta Membra Poetae: The Rhetoric of Dismemberment in Neronian Poetry.” In R. Hexter, D. Selden, eds., Innovations of Antiquity, 391-419. London, New York: Routledge.

Muecke, F., ed. 1993. Horace: Satires Book 2. Warminster: Aris and Phillips.

Nisbet, G., trans. 2015. Martial: Epigrams with Parallel Latin Text. A New Selection. Oxford: Oxford University Press.

Oliensis, E. 1998. Horace and the Rhetoric of Authority. Cambridge: Cambridge University Press.

Plaza, M. 2006. The Function of Humour in Roman Verse Satire: Laughing and Lying. Oxford: Oxford University Press.

Potter, D. S. 2012. “Tacitus' Sources.” In V. E. Pagán, ed., A Companion to Tacitus, 125-40. Malden, MA: Blackwell Publishing.

Ramsey, J. T., ed. 2003. Cicero: Philippics I-II. Cambridge: Cambridge University Press.

Reckford, K. J. 1998. "Reading the Sick Body: Decomposition and Morality in Persius' Third Satire." Arethusa 31: 337-54.

1999. "Only a Wet Dream? Hope and Skepticism in Horace, Satire 1.5." AJPh 120: $525-54$.

Richlin, A. 1992. The Garden of Priapus: Sexuality and Aggression in Roman Humor. New York: Oxford University Press.

Rohrbacher, D. 2010. "Physiognomics in Imperial Latin Biography." ClAnt 29: 92-116.

Rudd, N., ed. 1989. Horace: Epistles Book II and Epistle to the Pisones ("Ars Poetica"). Cambridge: Cambridge University Press.

Santoro L'hoir, F. 2006. Tragedy, Rhetoric, and the Historiography of Tacitus'Annales. Ann Arbor, MI: University of Michigan Press.

Schlegel, C. 2005. Satire and the Threat of Speech: Horace's Satires, Book 1. Madison: University of Wisconsin Press.

Shackleton Bailey, D. R., ed. and trans. 2001. Cicero: Letters to Friends, vol. 3. Cambridge, MA: Harvard University Press.

— , ed. and trans. 2009. Cicero. Philippics 1-6. Cambridge, MA: Harvard University Press. 
Skotheim, M. 2017. "Smelly Bodies on Stage: Disgusting Actors of the Roman Imperial Period.” In D. Lateiner, D. Spatharas, eds., The Ancient Emotion of Disgust, 267-76. Oxford: Oxford University Press.

Slater, W. J. 1976. "Symposium at Sea." HSPh 80: 161-70.

Wallace-Hadrill, A. 1995. Suetonius, 2nd ed. London: Bristol Classical Press.

Watson, L., ed. 2003. A Commentary on Horace's Epodes. Oxford: Oxford University Press.

Watson, L. and Watson, P., eds. 2014. Juvenal: Satire 6. Cambridge: Cambridge University Press.

West, D., trans. 1997. Horace: The Complete Odes and Epodes. Oxford: Oxford University Press.

Williams, C. A. 2012. Reading Roman Friendship. Cambridge: Cambridge University Press.

Wooten, C. W. 1983. Cicero's Philippics and Their Demosthenic Model. Chapel Hill, NC: University of North Carolina Press. 